Chirurgia (2021) 116: 214-223

No. 2, March - April

Copyright $\odot$ Celsius

http://dx.doi.org/10.21614/chirurgia.116.2.214

\title{
Tips and Tricks for Successful Breast Reconstruction Following Radiotherapy Using the Implant-Enhanced Latissimus Dorsi Flap
}

\author{
Ina Petrescu', Laurentiu Simion ${ }^{2,3^{*}}$, Ioana Mihaela Dogaru ${ }^{1,2}$ \\ 1Department of Plastic and Reconstructive Surgery, Emergency University Hospital, Bucharest, Romania \\ 2"Carol Davila" University of Medicine and Pharmacy, Bucharest, Romania \\ ${ }^{3}$ Department of Surgical Oncology, "Prof. Dr. Al. Trestioreanu” Institute of Oncology, Bucharest, Romania
}

*Corresponding author:

Associate Professor Laurentiu Simion, M.D., Ph.D.

Department of Surgical Oncology

"Prof. Dr. Al. Trestioreanu" Institute of Oncology, Bucharest, Romania

Soseaua Fundeni, no. 252

E-mail: lasimion@yahoo.com

\section{Rezumat \\ Aspecte ale reconstrucției mamare în cancerul de sân radiotratat, folosind lambou de latissimus dorsi și implant}

Introducere: Radioterapia adjuvantă crează cele mai serioase provocări pentru chirurgi, care trebuie să aleagă atât momentul, cât şi metoda reconstructivă optimă pentru pacientele iradiate. Una dintre tehnicile reconstructive postmastectomie, în cazurile care au necesitat iradiere, este metoda care combină țesutul propriu cu materialul aloplastic, respectiv lamboul latissimus dorsi şi implantul mamar. Această metodă este foarte versatilă şi poate fi aplicată în siguranță la pacientele radiotratate.

Material şi Metodă: $̂$ In perioada aprilie 2014 - aprilie 2020 am efectuat un număr de 219 reconstrucții mamare, din care 156 cazuri au fost reconstruite cu lambou latissimus dorsi şi implant. Principalele elemente studiate au fost: selecția pacientelor, indicația momentului operator şi tipului intervenției, măsurătorile şi desenul preoperator, cicatricea minimă a zonei donoare, decizia efectuării simetrizării simultane, a mastectomiei profilactice simultane cu reconstrucție imediată, aspectul cosmetic, stabilitatea şi evoluția rezultatelor în timp, urmărirea postoperatorie până la 5 ani.

Rezultate: Această tehnică s-a putut aplica în toate cazurile cu iradiere, indiferent de mărimea sânului contralateral, putând obține sâni de volume diferite. Aspectul cosmetic s-a îmbunătățit în timp, sânul având caracteristici similare cu cel sănătos - formă, ptoza naturală, consistență, şanț inframamar bine definit. 
Simetrizarea efectuată simulatan prin reducție mamară, mastopexie cu sau fără implant sau augmentare mamară a condus la rezulate superioare şi un grad ridicat de satisfacție a pacientei. Durata medie de recuperare a fost de 4 săptămâni, cu reinserția socio-profesională rapidă a pacientelor. Numărul mic de complicații - 1 necroză totală de lambou, 3 necroze parțiale, 5 seroame, cu un număr mic de reintervenții - 4, fac din această metodă una dintre dintre cele mai sigure în contextul dificil al zonei prepectorale iradiate.

Concluzii: Planificarea atentă a reconstrucției mamare cu ajutorul lamboului latissimus dorsi în combinație cu implantul mamar, tehnica minuțioasă determină rezultate stabile în timp, cu aspect cosmetic superior al sânilor reconstruiți prin această metodă, minimizând totodată şi riscul complicațiilor. Astfel calitatea vieții pacientelor este mult îmbunătățită, iar reinserția socioprofesională este relativ rapidă.

Cuvinte cheie: lambou latissimus dorsi, reconstrucție mamară, simetrizare sân

\begin{abstract}
Introduction: Adjuvant radiotherapy poses the most serious challenges for surgeons who must choose both the time and the optimal reconstructive method for radiotherapy patients. One of the postmastectomy reconstructive techniques, in patients subjected to radiotherapy, is the method that combines the own tissue with the alloplastic material, the latissimus dorsi flap and the breast implant. This method is highly versatile and can be safely applied to radiotherapy patients.

Materials and Methods: Between April 2014 and April 2020, we performed 219 breast reconstructions of which 156 cases were reconstructed with latissimus dorsi flap and implant. The main elements studied were: patient selection for the above mentioned technical procedure, indication of operative moment and type of intervention, preoperative measurements and sketching, minimal scar of the donor area, decision to perform simultaneous symmetrization, simultaneous prophylactic mastectomy with immediate reconstruction, cosmetic appearance, stability and evolution of results over time. The follow-up period was 1 year for all patients, while in the case of some patients up to 5 years.

Results: This technique could be applied in all cases with radiotherapy, regardless of the size of the contralateral breast, the technique allowing the shaping of breasts of different volumes. The cosmetic appearance has improved over time, the breast having characteristics similar to the healthy one - shape, natural ptosis, consistency, well-defined inframammary groove. Simultaneous symmetrization by breast reduction, mastopexy with or without implant or breast augmentation led to superior results and a high degree of patient satisfaction. The average duration of recovery was 4 weeks, with rapid social and professional reintegration of patients. The small number of complications - 1 total flap necrosis, 3 cases of partial necrosis, 5 seromas, with a small number of reinterventions - 4, make this method one of the safest in the difficult context of the radiotherapy treatment of prepectoral area.

Conclusions: Careful planning of breast reconstruction with the help of the latissimus dorsi flap in combination with the breast implant, the meticulous technique determines stable results over time, with superior cosmetic appearance of the breasts reconstructed with the aid of this method, while minimizing the risk of complications. Thus, the quality of life of patients is much improved, and the social and professional reintegration is relatively fast.
\end{abstract}

Key words: latissimus dorsi flap, breast reconstruction, breast symmetrisation, radiotherapy 


\section{Introduction}

More than half of the surgeries for breast cancer in Romania are mastectomies, a fact caused in part by the detection in advanced stages, the late presentation of patients to the doctor, as well as the collective mentality. Globally, the percentage of mastectomies varies between $10-15 \%$ and $80-90 \%$ in Western Europe, the United States, and Canada (1). Postoperative radiotherapy, which invariably follows in these cases, requires the option of delayed reconstruction (2).

Ionizing radiation, used either on the chest wall or on the armpit, irreversibly alters the tissues in the treated area, regardless of their nature. In the short term, there is erythema and scaling of the skin, and in the long term severe fibrosis, telangiectasia, hyperpigmentation and tissue atrophy (3). Basically, the irradiated tissues - the skin, the subcutaneous cellular tissue, and the muscle lose their natural elastic properties, often the area becoming hard, and the creation of a retropectoral pocket is very difficult. Thus, in order to create a new breast, it is necessary to bring well-vascularized tissue - and the latissimus dorsi flap easily fulfils these desiderata. However, it is often necessary to obtain the desired volume and add a breast implant. The aim of this study is to evaluate breast reconstruction, using the above mentioned technique, in radiotherapy treated patients, by highlighting the results obtained.

The myocutaneous latissimus dorsi flap was first described by Tansini (4) in 1906 and then readapted for breast reconstruction by Schneider (5) and Botswick (6) in the late 1970s. This classic flap is still an important alternative in postradiotherapy breast reconstruction, proving safe in over $95 \%$ of cases (7). It offers practical solutions to the multiple problems specific to the irradiated chest, bringing healthy and well-vascularized tissue to support the implant, while providing a natural appearance of the reconstructed breast (8).

\section{Materials and Methods}

The unicenter retrospective study was performed over a period of 6 years, selecting patients with breast cancer who underwent complex cancer treatment. The inclusion criteria in the study were: breast cancer, mastectomy with axillary lymph node dissection, breast reconstruction secondary to oncological treatment, the use of latissimus dorsi flap and implant as a reconstruction technique. Exclusion criteria: patients with no radiotherapy and those in whom the reconstruction was performed using another technical procedure.

Between April 2014 and April 2020, we performed 219 breast reconstructions, of which 156 were secondary reconstructions with latissimus dorsi flap and implant. The age of the patients ranged from 27 to 70 years. Of these, 148 patients underwent radiotherapy. Bilateral reconstruction by this technique was performed in 2 cases, and in 21 patients, simultaneous symmetrization was performed. In 6 patients, an operation was performed at the same time with secondary reconstruction and prophylactic mastectomy, with immediate reconstruction of the contralateral breast.

The study was conducted under the ethical principles in force, with the consent of the health units involved. Informed consent of all patients was obtained and all legal measures were taken to protect personal data. Patients' consent to use the photographs was also obtained.

\section{Preoperative Planning}

An important step is the choice of patients, and the main criteria used were: at least 6 months after the end of radiotherapy, stable patients from an oncological point of view, favorable opinion of the oncologist, lack of chronic unbalanced diseases, exclusion of grade II and III obesity and mental illness, imaging contralateral breast without lesions BIRADS $>2$. In the case of prophylactic mastectomies, the criteria were: genetic criteria (presence of BRCA 1 or 2), fibrocystic 
mastopathy, strong family history ( $>2$ direct female relatives diagnosed with breast cancer).

The preoperative sketch is the crucial step in the success of reconstruction, and planning must be done very carefully. We will always consider the key elements: the status of the healthy breast (volume, shape, degree of ptosis), the condition of the irradiated prepectoral area (whether there is a degree of local adipocutaneous excess or not, the transverse size depending on which the implant base is chosen), as well as excess adipocutaneous at the level of the ipsilateral, infrascapular posterior hemithorax (verified by "pinch test"). The orientation of the skin flap is transversal, but it can be placed, depending on the direction of the mastectomy scar, with different degrees of obliquity.

Knowing well the volume of the implants or using sizers (if available) we can estimate the volume of the future breast and also we can plan what type of symmetry we choose for the contralateral breast.

The key elements of the preoperative sketch must include: marking the pocket and the inframammary groove, which, on the mastectomy side, is performed in reference to the healthy breast, but also superior, medial, 2 $\mathrm{cm}$ from the mid-sternal line, and laterally to the anterior axillary line. The marking of the flap is done as follows: the skin flap with an ellipsoidal shape, with a long diameter arranged transversely, marking at the same time the tip of the scapula and the median prevetebral line. Also, the preoperative sketch necessary for the symmetry of the healthy breast will be performed. We must ensure that during the intervention the markings are resistant to erasure, so as not to lose the essential guiding points.

\section{Surgical Technique}

The surgical technique has a medium degree of difficulty, being at the disposal of an experienced plastic surgeon. In most cases we opted for harvesting the latissimus dorsi muscle-skin flap. In the first stage, a mixed pre- and retropectoral pocket is created, then the patient is positioned in lateral decubitus, with the armpit open at an angle of 90 and the flap is prepared as follows: ellipsoid skin flap designed transversely, so that the donor area closes with a hidden incision in the bustier, the available volume of skin and subcutaneous cellular tissue is assessed by "pinch test", to suture the donor area without excessive tension.

After the incision of the subcutaneous flap, the subcutaneous dissection of the flap is performed, followed by the lifting of the latissimus dorsi muscle from the deep plane and the complete disinsertion of the muscle. The thoraco-dorsal vascular pedicle is not skeletalized, the adjacent fascial structures are maintained for its protection, and the flap is tunneled through the armpit to the preretropectoral mixed pocket. Closing the donor area is done in 3 layers, with absorbable threads. The installation of a drain is not mandatory in the conditions of a careful hemostasis.

The new breast is created by placing the retropectoral breast implant and the prepectoral flap. The good contention of the implant, in order to avoid the lateralization in the armpit of the new breast, is achieved by fixing with slow resorbable threads of the pectoralis major muscle, by separated threads, to the subcutaneous tissue, in the lower pole of the pocket, which is often fibrotic due to radiotherapy, a procedure that will ensure suture resistance. The muscle flap is fixed to the pectoral muscle in the upper pole by separate threads and lower part to the subcutaneous tissue of the lower pole of the pocket. Closure is done subcutaneously, by continuous and intradermal suturing. One suction drainage is installed in each of the two areas. Drainage is suppressed a few days postoperatively or when there is no production (if complications occur). The vascularity of the flap is checked, and it must have a color similar to that of the receptor area and normal capillary pulse. The breast implants used are round, to avoid rotation and consequently distortion of the new breast, which could occur in the case of anatomical implants. The projection of the 
implant is moderate, because the flap brings additional projection. The volume of the implants was between $120 \mathrm{cc}-360 \mathrm{cc}$.

The surgical technique must be atraumatic, so as not to compromise the vascularization of the flap and, except for the classic incision with the scalpel, the dissection will be performed with electrocautery.

In cases in which simultaneous symmetry is chosen, various contralateral breast adjustment procedures can be performed - either reduction or mastopexy with or without implant, or simple augmentation with implant (if the healthy breast is very small and the reconstructed breast will have a sufficiently large volume). Simultaneous symmetrization involves various cosmetic surgery techniques to obtain a final result with superior cosmetic appearance.

In case of performing the subcutaneous mastectomy simultaneously on the contralateral breast, with immediate reconstruction with implant, we performed the mastectomy simultaneously with the first stage of creating the pocket for the reconstructed breast. Implant reconstruction was performed as soon as the breast reconstructed with flap and implant was completed, to the intradermal suture stage, to determine the volume of implant required; for this we used a special intraoperative sizer. The duration of the surgeries, depending on the degree of complexity, was between $2 \mathrm{~h}$ and $15 \mathrm{~min}$ and $5 \mathrm{~h}$, in the case of bilateral breast reconstructions with latissimus dorsi flap and implant.

Postoperatively, the patients received antibioprophylaxis with cephalosporins, analgesics, the patients were mobilized shortly after 3-4 h, and wore a bustier permanently for 2 months, during which time they avoided physical exertion. The patients were allowed to return to her professional activity 1 month after surgery. At 3 weeks, the local treatment of the scars with silicone gels was commenced and is done daily for 3 months. The duration of hospitalization was on average 2-3 days.

\section{Results}

Reconstruction with latissimus dorsi flap and implant could be performed in the case of all patients treated with radiotherapy, regardless of the size of the contralateral breast, obtaining breasts of different volumes, adjusted to each case. The cosmetic appearance has improved over time, the reconstructed breast having characteristics similar to the healthy one. Simultaneous symmetrization by breast reduction, mastopexy with or without implant or breast augmentation led to superior results and a high degree of patient satisfaction.

The average duration of recovery was 4 weeks, with rapid social and professional reintegration of patients.

Regarding the complications, besides the small number, we can detail:

- 1 total flap necrosis, which was caused by damage to the thoracodorsal vascular pedicle during the previous mastectomy intervention; in this situation, after the removal of the necrotic flap, reconstruction with breast implant was performed;

- 3 partial flap necrosis, these were removed, leaving the area to directed epithelialization;

- 5 wound sera of small volume, which were treated on an outpatient basis, by repeated evacuations and compressive dressing;

- a small number of reinterventions - only 4 !

The presence of the flap next to the implant ensures that the reconstructed breast has properties which are clearly superior to the simple reconstruction with a breast implant the breast has a shape, ptosis, and consistency similar to a healthy breast, and the inframammary groove is well defined. With the help of this surgical technique we were able to obtain breasts of various volumes. The appearance over time is preserved. The included photographs (Figs. 1- 7 ) emphasize the results that we obtained. The scar of the donor area is masked by the bustier (Fig. 8).

The use of muscle with the sacrifice of its function is well tolerated in most cases, even in athletic patients (9). In a 2015 study, Yang 
Figure 1. Reconstruction with latissimus dorsi flap and $325 \mathrm{cc}$ breast implant; immediate symmetry by augmentation with a $300 \mathrm{cc}$ implant in the case of a small volume contralateral breast

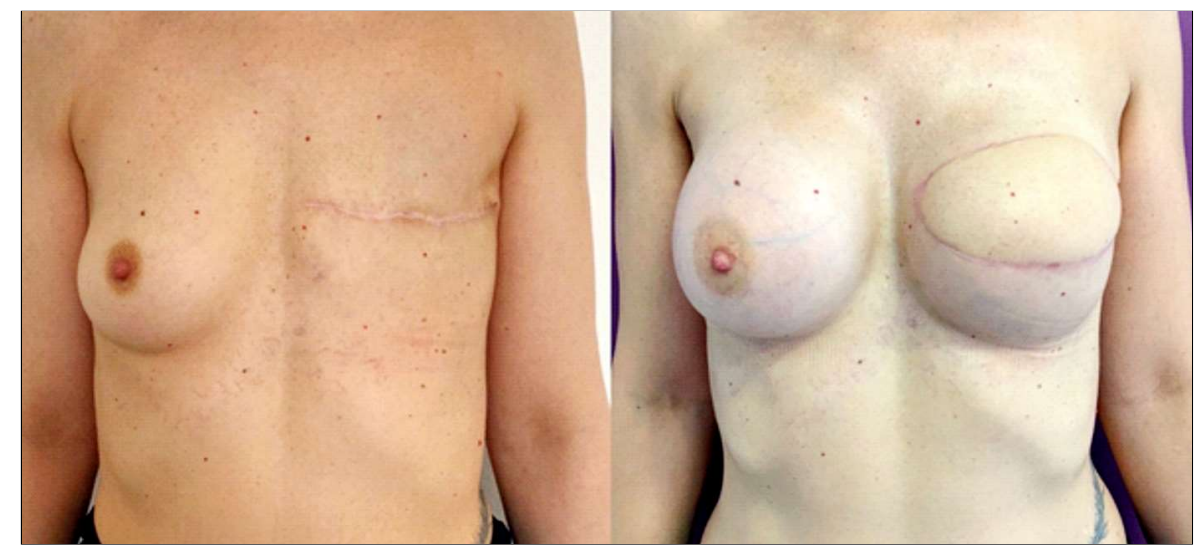

Figure 2. Reconstruction with latissimus dorsi flap and $325 \mathrm{cc}$ round breast implant; in the case of the contralateral breast, with small ptosis and moderate volume, it does not require symmetrization

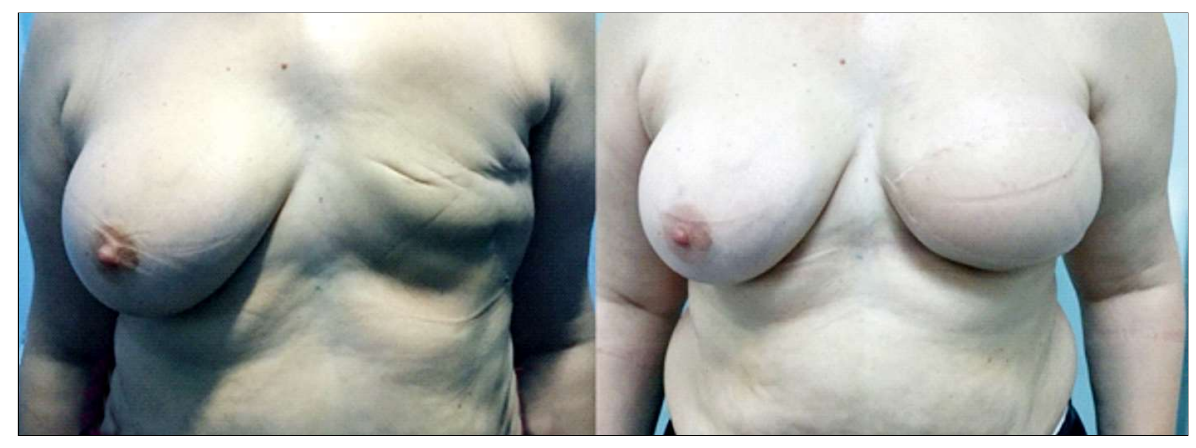

Figure 3. Reconstruction with latissimus dorsi flap and $350 \mathrm{cc}$ breast implant; secondary symmetry by mastopexy in the case of large volume contralateral breast

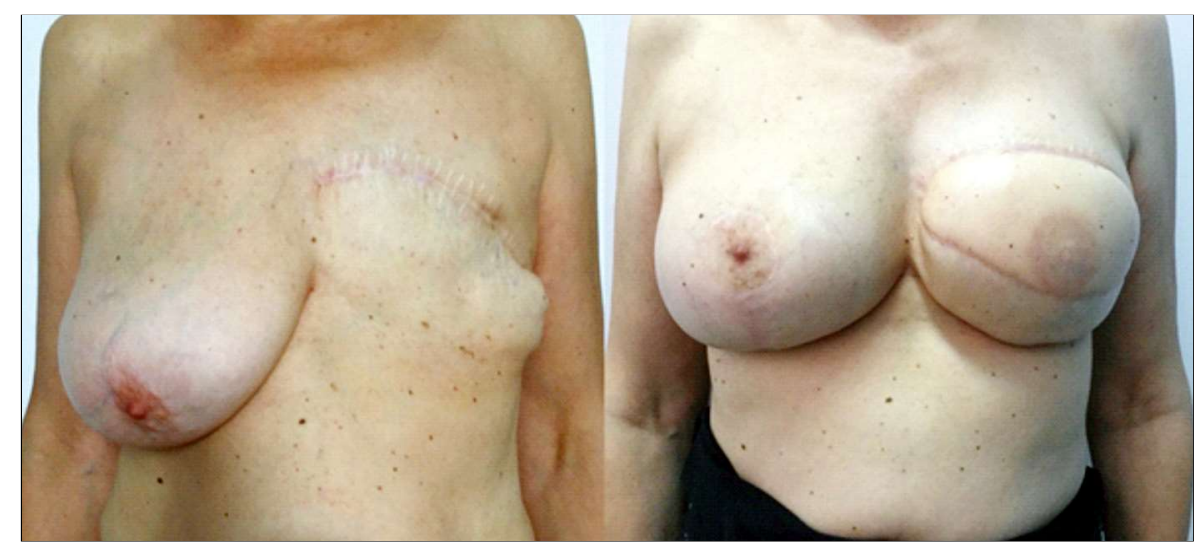

Figure 4. Reconstruction with latissimus dorsi flap and $350 \mathrm{cc}$ breast implant; simultaneous contralateral breast symmetry by breast reduction with the superomedial pedicle

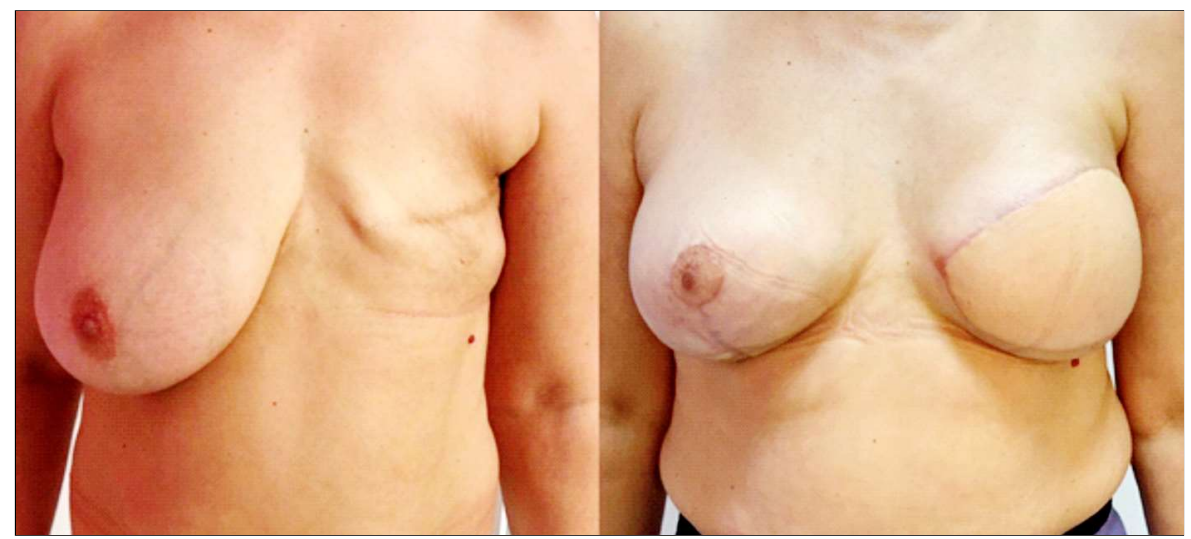


Figure 5. Reconstruction with latissimus dorsi flap and $325 \mathrm{cc}$ round breast implant; simultaneous prophylactic mastectomy contralateral breast with immediate reconstruction with round breast implant $375 \mathrm{cc}$
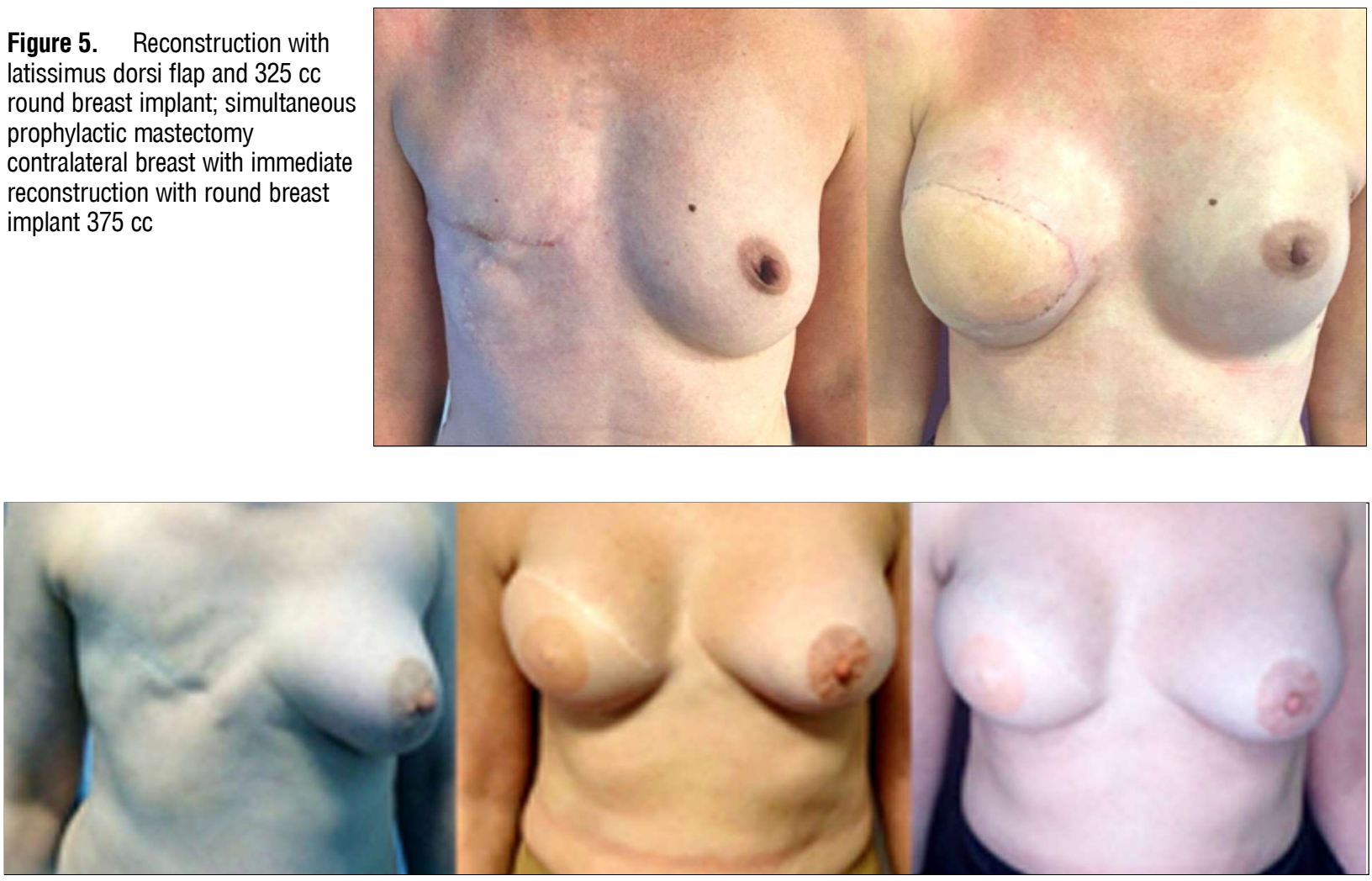

Figure 6. Breast reconstruction with latissimus dorsi flap and $275 \mathrm{cc}$ breast implant; contralateral symmetrization by mastopexy with breast implant $225 \mathrm{cc}$, appearance at 5 and 6 years postoperatively

et al. (10) showed that at 3 months, muscle strength was comparable to preoperative levels, but limiting patient activity and perception remained unchanged until about 1 year after surgery.

Due to the very good vascularization of this flap, the technique is advantageous in obese patients, ischemia or necrosis of the flap being very rarely encountered (9).
Moreover, with the help of this technique we saved cases with previously failed reconstructions, this provig to be a useful tool in these situations.

\section{Discussions}

The use of latissimus dorsi muscle with the sacrifice of its function is well tolerated in
Figure 7. Simultaneous bilateral breast reconstruction with latissimus dorsi flap and 300 cc breast implant, appearance 1 year postoperatively

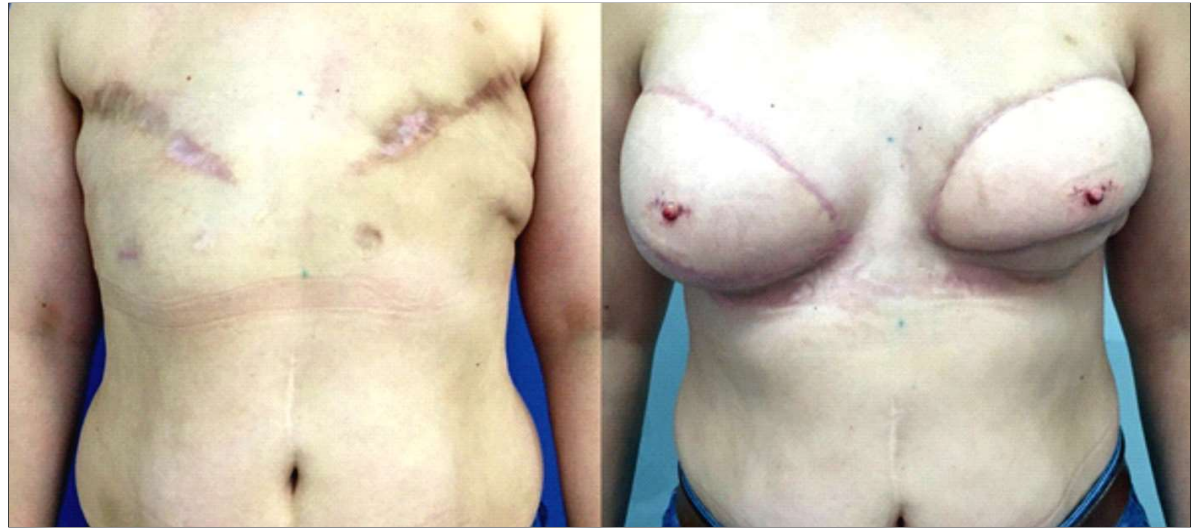

www.revistachirurgia.ro 


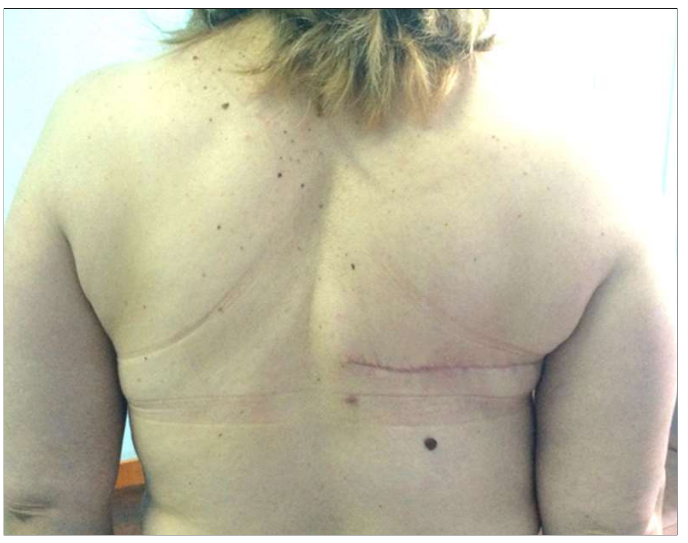

Figure 8. The scar of the donor area, concealed by the bustier

most cases, even in athletic patients (9). In a 2015 study, Yang et al. (10) showed that at 3 months, muscle strength was comparable to the preoperative level, but limiting activity and patient perception remained unchanged until about 1 year after surgery.

Most authors recommend the use of flaps instead of breast implants in radiotherapy cases, due to the very high percentage of complications. However, not all radiotherapy patients can benefit from reconstruction only with their own tissue, as they did not have excess abdominal tissue to perform a reconstruction with TRAM flap (transverse rectus abdominis muscle, right abdominal muscle flap and abdominal fat) or DIEP (flap harvested on perforating vessels of the inferior epigastric artery, flap of abdominal fat) (11). However, for absolutely all patients in the study group, reconstruction with latissimus dorsi flap and implant could be performed, with the adipocutaneous resource on the posterior thorax, which proves the special utility of this method.

Regarding the operative moment of the reconstruction, there are several situations that need to be managed. The simplest is the one in which the reconstruction is performed after the patient has entirely completed the oncological treatment (including radiotherapy), the N.C.C.N. guide (National Comprehensive Cancer Network) recommending reconstruction at the earliest 6 months postoperatively. Increasingly, in cases that require postoperative radiotherapy, immediate reconstruction with an expander is recommended, and after the end of radiotherapy, the replacement of the expander with the patient's own tissue or the combination of own tissue and implant. The goal is to preserve as much skin as possible for reconstruction. If patients no longer need radiotherapy, the expander is replaced every 2 weeks by an implant or autologous tissue (12).

All our patients had an obvious increase in the quality of life: they no longer have to wear an external prosthesis, they can wear low-cut neck garments, but also the social, professional and the couple's life has improved in many of the cases. Regarding the esthetic result of the reconstruction, Lindegren et al. (13) conducted a study on 70 radiotherapy who benefited from secondary autologous reconstruction. The study compared the perception of patients and surgeons on the results after latissimus dorsi flap or DIEP (flap of abdominal fat). Surgeons preferred results after DIEP for the natural shape and volume of the breast, while patients were more satisfied with the results of the latissimus dorsi flap, an unexpected result by the authors, probably correlated with greater satisfaction in the latter case regarding the donor scar area.

\section{Complications}

Although rare, 1 case with total flap necrosis should be mentioned, the cause of which was the injury of the thoracodorsal vascular pedicle during the previous mastectomy intervention. In this situation, after removing the necrotic flap, the reconstruction was performed with a breast implant.

In the case of partial necrosis, necrotic areas were removed, leaving the area epithelialized.

Cases with low-volume serum were treated on an outpatient basis, by repeated evacuation and compressive dressing.

Radiotherapy, with its increasingly varied indications in the field of breast cancer, significantly changes postoperative outcomes. The impact on the complications of reconstruction is significantly increased in the case 
of alloplastic procedures, better results being recorded in autologous reconstructions. ElSabawi et al. (13) conducted a systematic analysis of radiotherapy-treated patients, in which they observed that those with autologous reconstruction had a lower rate of postoperative complications $(30.9 \%$ vs. $41.3 \%)$, with the prevalence of complications related to healing, wounds, hematomas, and seromas, while infections and reinterventions prevailed in cases where the implant was used (14).

The technique of breast reconstruction with latissimus dorsi flap is also used after various various oncological breast surgery interventions, not only after modified radical mastectomy (15), both in immediate and secondary reconstructions, either simple flap, or in combination with implant.

The available studies do not agree on the optimal method of breast reconstruction, as shown by a review of the literature available on PubMed for the years 2000 - 2016. (16) Reconstruction with latissimus dorsi flap is among the preferred techniques, especially considering the rendered results, either in the classic version, flap and breast implant, or in the flap version and Becker expander implant (17). In the case of secondary reconstructions of the breast, or in the case of reinterventions after a failed reconstruction, in radiotherapy treated patients, the latissimus dorsi flap technique (associated with implant or expander) has proven to be the most frequently used (18)

Breast reconstruction with latissimus dorsi flap provided very good cosmetic results even in the group of weak patients, with low body mass index, low volume of the remaining breast, which is why the technique is recommended in these difficult cases (19). In fact, this technique is still preferred, even if new microsurgical procedures have been described. Latissimus dorsi flap reconstruction is a reliable method which can be performed in all patients, including postradiotherapy, offering the possibility of a breast augmentation, within reasonable limits, when the patient wishes (20).
The use of the latissimus dorsi flap did not prove to have any negative effect on the position of the back or on the function of the shoulder joint, the radiotherapy treated patients who benefited from this type of reconstruction being extremely satisfied with the final result, both in terms of esthetics and function.

\section{Conclusions}

Breast reconstruction nowadays is an essential step in a multidisciplinary approach to breast cancer. The multitude of therapeutic options available makes this procedure feasible in more complex situations and, thus, patients can benefit from the appropriate technique for each case.

Breast reconstruction with latissimus dorsi flap and implant is an excellent alternative in cases with postmastectomy radiotherapy, being an extremely versatile method, whereas its careful planning and atraumatic technique ensures a superior esthetic appearance of the reconstructed breast. Thus, the quality of life of patients is superior, and their social and professional reintegration is relatively fast.

\section{Conflict of Interest}

The authors declared no potential conflicts of interest with respect to the research, authorship, and/or publication of this article.

\section{Ethics Approval}

The study was conducted respecting the actual ethical principles, with the consent of the health units involved. Informed consent of all patients was obtained and all legal measures were taken to protect personal data. Patients' consent to use the photographs was also obtained.

\section{References}

1. Fisher B, Anderson S, Bryant J, Margolese RG, Deutsch M, Fisher ER, et al. Twenty-year follow-up of a randomized trial comparing total mastectomy, lumpectomy, and lumpectomy plus irradiation for the treatment of invasive breast cancer. N Engl J Med. 2002; 347(16):1233-41. 
2. Lennox PA, Bovill ES, Macadam SA. Evidence-Based Medicine: Alloplastic Breast Reconstruction. Plast Reconstr Surg. 2017;140(1): 94e-108e.

3. See MSF, Farhadi J. Radiation Therapy and Immediate Breast Reconstruction. Novel Approaches and Evidence Base for Radiation Effects on the Reconstructed Breast. Clin Plastic Sur 2018;15:13-24.

4. Maxwell GP. Iginio Tansini and the origin of the latissimus dorsimusculo cutaneous flap. Plast Reconstr Surg. 1980;65(5):686-692.

5. Schneider WJ, Hill HL Jr, Brown RG. Latissimus dorsi myocutaneous flap for breast reconstruction. Br J Plast Surg. 1977; 30(4):277-281.

6. Bostwick J III, Vasconez L0, Jurkiewicz MJ. Breast reconstruction after a radical mastectomy. Plast Reconstr Surg. 1978;61(5):682-693.

7. Bostwick J 3rd. Breast reconstruction following mastectomy. CA Cancer J Clin. 1995;45(5):289-304

8. SL Spear, JH Boehmler, DP Bogue, Mafi AA. Options in reconstructing the irradiated breast. Plast Reconstr Surg. 2008;122(2):379-388.

9. Hammond DC. Latissimus dorsi flap breast reconstruction. Plast Reconstr Surg. 2009:124(4):1055-1063.

10. Yang JD, Huh JS, Min YS, Kim HJ, Park HY, TD Jung. Physical and functional ability recovery patterns and quality of life after immediate autologous latissimus dorsi breast reconstruction: a 1-year prospective observational study. Plast Reconstr Surg. 2015; 136(6):1146-1154.

11. Spear SL, Boehmler JH, Bogue DP, Mafi AA. Options in reconstructing the irradiated breast. Plast Reconstr Surg. 2008;122(2): 379-388.

12. Panchal $\mathrm{H}$, Matros E. Current Trends in Postmastectomy Breast Reconstruction. Plast Reconstr Surg. 2017;140(5S Advances in Breast Reconstruction):7S-13S

13. Lindegren A, Halle M, Docherty Skogh AC, Edsander-Nord T. Postmastectomy breast reconstruction in the irradiated breast: a compara- tive study of DIEP and latissimus dorsi flap outcome. Plast Reconstr Surg. 2012;130(1):10-18

14. El-Sabawi B, Sosin M, Carey JN, Nahabedian MY, Patel KM. Breast reconstruction and adjuvant therapy: a systematic review of surgical outcomes. J Surg Oncol. 2015;112(5):458-64.

15. Sood R, Easow JM, Konopka G, Panthaki ZJ. Latissimus Dorsi Flap in Breast Reconstruction: Recent Innovations in the Workhorse Flap, Cancer Control. 2018;25(1):1073274817744638.

16. Yun JH, Diaz R, Orman AG. Breast Reconstruction and Radiation Therapy, Cancer Control. 2018;25(1):1073274818795489.

17. Dutra AK, Junior JA, Fernandes ACN. Delayed breast reconstruction with transverse latissimus dorsi myocutaneous flap using Becker expander implants in patients submitted to radiotherapy: A series of cases, J Plast Reconstr Aesthet Surg. 2019;72(7):1067-1074.

18. DeLong MR, Tandon VJ, Rudkin GH, Da Lio AL. Latissimus Dorsi Flap Breast Reconstruction-A Nationwide Inpatient Sample Review, Ann Plast Surg. 2017;78(5 Suppl 4):S185-S188.

19. Kazzazi F, Ching RC, Malata CM. Postmastectomy Breast Reconstruction With the Totally Autologous Latissimus Dorsi Flap in the Thin, SmallBreasted Woman: Give It More Thought! Eplasty. 2018;18:e13.

20. Bruant-Rodier C, Ruffenach L, Hendriks S, Bodin F, Dissaux C. Breast reconstruction by latissimus dorsi myocutaneous flap and implant: The dorsal bra technique. Ann Chir Plast Esthet. 2018; 63(5-6):405-421. French.

21. Tenna S, Salzillo R, Brunetti B, Morelli Coppola M, Barone M, Cagli B, et al. Effects of latissimus dorsi (LD) flap harvest on shoulder function in delayed breast reconstruction. A long-term analysis considering the acromiohumeral interval (AHI), the WOSI, and BREAST-Q questionnaires, J Plast Reconstr Aesthet Surg. 2020; 73(10):1862-1870. 